\title{
Impacts and Management of Hemlock Woolly Adelgid in National Parks of the Eastern United States
}

Author(s): Scott R. Abella

Source: Southeastern Naturalist, 13(6):16-45.

Published By: Eagle Hill Institute

URL: http://www.bioone.org/doi/full/10.1656/058.013.s614

BioOne (www.bioone.org) is a nonprofit, online aggregation of core research in the biological, ecological, and environmental sciences. BioOne provides a sustainable online platform for over 170 journals and books published by nonprofit societies, associations, museums, institutions, and presses.

Your use of this PDF, the BioOne Web site, and all posted and associated content indicates your acceptance of BioOne's Terms of Use, available at www.bioone.org/page/ terms of use.

Usage of BioOne content is strictly limited to personal, educational, and non-commercial use. Commercial inquiries or rights and permissions requests should be directed to the individual publisher as copyright holder. 


\title{
Impacts and Management of Hemlock Woolly Adelgid in National Parks of the Eastern United States
}

\author{
Scott R. Abella*
}

\begin{abstract}
Introduced forest pests and pathogens are a major threat to national parks. This paper reviews existing impacts, projected impacts, and management options for Tsuga canadensis (Eastern Hemlock) forests in US national parks threatened by the introduced insect Adelges tsugae (Hemlock Woolly Adelgid [HWA]). Eighty-five national parks, or $21 \%$ of all parks in the US national park system, are encompassed within the range of Eastern Hemlock. These 85 parks include iconic areas such as national battlefields and the Appalachian National Scenic Trail. Four focal parks of this study-Delaware Water Gap National Recreation Area, Great Smoky Mountains National Park, Shenandoah National Park, and New River Gorge National River - are collectively visited by 16 million people annually and Eastern Hemlock is a forest component in 2-26\% of their area. Results of research on HWA impacts to forest species composition, soil nutrient cycling, watersheds and fisheries, wildlife habitat, and visitor experiences and safety have already been reported from these parks. A general principle is that after Eastern Hemlock forest decline, some species (e.g., some avian species favoring other tree species) benefit, while those associated with Eastern Hemlock must adapt or decline. Forecasting future forest-tree composition is complicated by the fact that: (i) many possible replacement tree species are themselves threatened by introduced damaging agents, (ii) changes hinge upon understory dynamics such as invading exotic plants or expansion of native shrubs, and (iii) this die-off event is occurring within a context of multiple interacting factors such as elevated herbivory, climate change, and atmospheric pollution. Some management strategies for parks include: intensive HWA chemical treatment at priority sites, biocontrol, genetic manipulation for HWA resistance in Eastern Hemlock, exotic plant treatment, facilitated establishment of native vegetation, or doing nothing, the last of which also is likely to result in appreciable forest change. Threats to US national parks posed by introduced forest pests and pathogens warrant heightened attention.
\end{abstract}

\section{Introduction}

The potential for introduced forest pests and pathogens to degrade resources of national parks is formidable. The 1916 Organic Act (39 Stat. F35) created the National Park Service (NPS) with the long-term mission of conserving, unimpaired, significant US natural and cultural features for future generations. This mission was reaffirmed by the 2006 NPS management policy that defined impairment as a direct impact to a resource or value that is: (i) necessary to fulfilling specific purposes identified in a park's establishing legislation, (ii) key to a park's natural or cultural integrity, or (iii) identified in a park's management plan as being of critical

\footnotetext{
*National Park Service, Washington Office, Natural Resource Stewardship and Science Directorate, Biological Resource Management Division, 1201 Oakridge Drive, Fort Collins, CO 80525. Current address - Natural Resource Conservation LLC, 1400 Colorado Street, Boulder City, NV 89005; abellaNRC@gmail.com.
}

Manuscript Editor: Justin Hart 
significance (NPS 2006). Forest die-offs caused by introduced pests and pathogens could meet criteria for impairment because indigenous forests represent inherent resource values, forests influence many other natural and cultural resource values, and multiple human generations are required for old forests to develop.

Reducing or forestalling degradation from introduced forest-damaging agents is a major challenge for the NPS and one that is expected to increase in difficulty (Jenkins 2007). Numerous examples of major alterations to forest species composition caused by introduced organisms already exist (Liebhold et al. 1995). A classic example in eastern North America is Castanea dentata (Marshall) Borkh. (American Chestnut). This native tree was eliminated as a dominant canopy species by the 1950s, including in national parks, because of the introduced fungus Cryphonectria parasitica (Murrill) Barr that caused Chestnut Blight (Ellison et al. 2005). Thus, this damaging agent had already dramatically impacted parks long before the past few decades of recent climatic change (Lovett et al. 2006). In addition to introduced fungi, over 450 species of exotic forest insects have been introduced to North America (Aukema et al. 2009). Many of these introduced organisms are still expanding their ranges, further underscoring their potential to impact national parks. The introduced insect Adelges tsugae Annand (Hemlock Woolly Adelgid [HWA]) that is killing Tsuga canadensis (L.) Carrière (Eastern Hemlock) trees in eastern North America exemplifies the type of recent impact already incurred and suggests the potential for future impacts to parks (Eschtruth et al. 2006). Moreover, responses to this introduced pest illustrate issues in contemporary management that seek to reduce impacts or facilitate forest adaptation to damaging agents in parks (Johnson et al. 2008).

This review has three focus areas. First, it summarizes Eastern Hemlock ecology, HWA ecology, and the value of Eastern Hemlock forests to parks threatened by HWA. Second, it synthesizes data regarding existing and potential impacts of HWA to four large HWA-infested parks where research has been conducted, and then broadens discussion of potential impacts by including lands surrounding parks. Third, it discusses potential management strategies for Eastern Hemlock forests in a national park context and presents ideas for integration of forest health with NPS programs. This emphasis on NPS lands for the HWA threat is timely, because while a large body of literature is accumulating on HWA, national parks have some unique considerations that differ from other lands. Moreover, several aspects of HWA management, such as release of biocontrols or long-term genetic manipulation for HWA resistance in Eastern Hemlock, illuminate challenges faced by managers who must comply with existing NPS policy.

\section{Ecology and Values of Eastern Hemlock Forests}

\section{Eastern Hemlock autecology}

Eastern Hemlock is an evergreen, coniferous tree in the Pinaceae family. Godman and Lancaster (1990) reported that ages over 400 years, diameters greater than 100 $\mathrm{cm}$, and heights of $30 \mathrm{~m}$ or more are common for Hemlock trees in mature stands. Eastern Hemlock is ranked as the most shade-tolerant of eastern tree species and it 
can survive with only 5\% full sunlight (Goerlich and Nyland 2000). The slow-growing species can remain as a suppressed seedling or sapling for centuries, but given a canopy opening at any point after seedling establishment, it can grow $\approx 0.6 \mathrm{~cm} / \mathrm{yr}$ in diameter (Godman and Lancaster 1990). Eastern Hemlock relies on a seedling bank for recruitment, because while seed production is plentiful, seeds stored in the soil rarely retain viability more than one year (Hille Ris Lambers et al. 2005). Cones and the seeds inside them are small, and the seeds are wind dispersed starting in October and continuing through winter, depending on geographic location (Goerlich and Nyland 2000). The species does not resprout if cut (Orwig and Foster 1998). Eastern Hemlock is susceptible to several native and exotic fungi (e.g., root rots) and insects that can damage or kill trees, but none are presently as devastating as HWA. Hemlock's unique combination of large size, longevity, shade tolerance, and evergreen growth form is not readily replaced by other eastern tree species.

Eastern Hemlock has high moisture requirements, is susceptible to drought, and might have reduced resistance to damaging agents on dry sites (Orwig et al. 2002). In the southern part of its range, Eastern Hemlock typically is most dominant on moist sites near streams, in drainages, or on topographically protected sites or north aspects with damp, cool microclimates (Abella 2003, Hart and Shankman 2005, Kincaid 2007). In northern areas, Eastern Hemlock occupies sites similar to those in the South, as well as margins of swamps and lakes, and moist upland areas (Orwig et al. 2012). Soil properties are variable on sites occupied by Eastern Hemlock (Abella et al. 2003). Hemlock can form pure stands or grow in mixtures with numerous other tree species varying within landscapes and among regions of its range (Evans et al. 2011). Thus, extirpation of Eastern Hemlock would result in complete stand replacement in pure Eastern Hemlock stands or alteration of mixed-species stands (Fig. 1).

Eastern Hemlock's recent biogeographic history reveals that a major decline occurred in the past that is thought to have correlated with an extended dry period (Hessl and Pederson 2013). Based on a study of buried pollen in Ontario, Canada Eastern Hemlock expanded its importance in the region beginning ca. 9000 years ago (Haas and McAndrews 2000). However, starting ca. 5800 years ago, Eastern Hemlock declined about 6 -fold during the next 1000 years when the climate warmed and precipitation decreased from 83 to $70 \mathrm{~cm} / \mathrm{yr}$. Pollen of Pinus spp. (pine), Betula spp. (birch), Fagus spp. (beech), Ulmus spp. (elm), Acer spp. (maple), and Quercus spp. (oak) increased or was maintained during a 2000-yr period from the start of Eastern Hemlock's decline 5800 until 3800 years ago when Eastern Hemlock began increasing. Thus, while Eastern Hemlock suffered a fairly recent major decline, it is not thought to be as severe as today's HWA-induced collapse. Moreover, new stressors are prevalent (e.g., introduced organisms affecting tree species that increased during Hemlock's past decline) that could influence forest changes (Ford et al. 2012, Small et al. 2005, Snyder et al. 2011).

\section{Value of Eastern Hemlock forests}

Eastern Hemlock is considered a foundation species because it performs a unique set of ecological functions not necessarily provided by any other tree species in 
eastern North American forests (Ellison et al. 2005, Vose et al. 2013). This species plays a role in microclimate amelioration, watershed stabilization, soil ecology, and nutrient cycling, as well as affecting plant species composition in forest communities and wildlife habitat. Eastern Hemlock also has aesthetic and economic value for humans (Table 1).

Because of its evergreen foliage and high crown-bulk density, Eastern Hemlock creates a unique microclimate that moderates conditions throughout the year. In summer, its foliage creates a dark, cool, moist microclimate below its canopy that has important implications for habitat and watershed functions. In the southern Appalachian Mountains of North Carolina for example, Webster et al. (2012) found that a doubling of per hectare Eastern Hemlock foliage mass resulted in a $15 \%$ decrease in mean summer temperature. During winter, Eastern Hemlock can ameliorate extreme temperatures and snowfall. In Vermont, Lishawa et al. (2007)

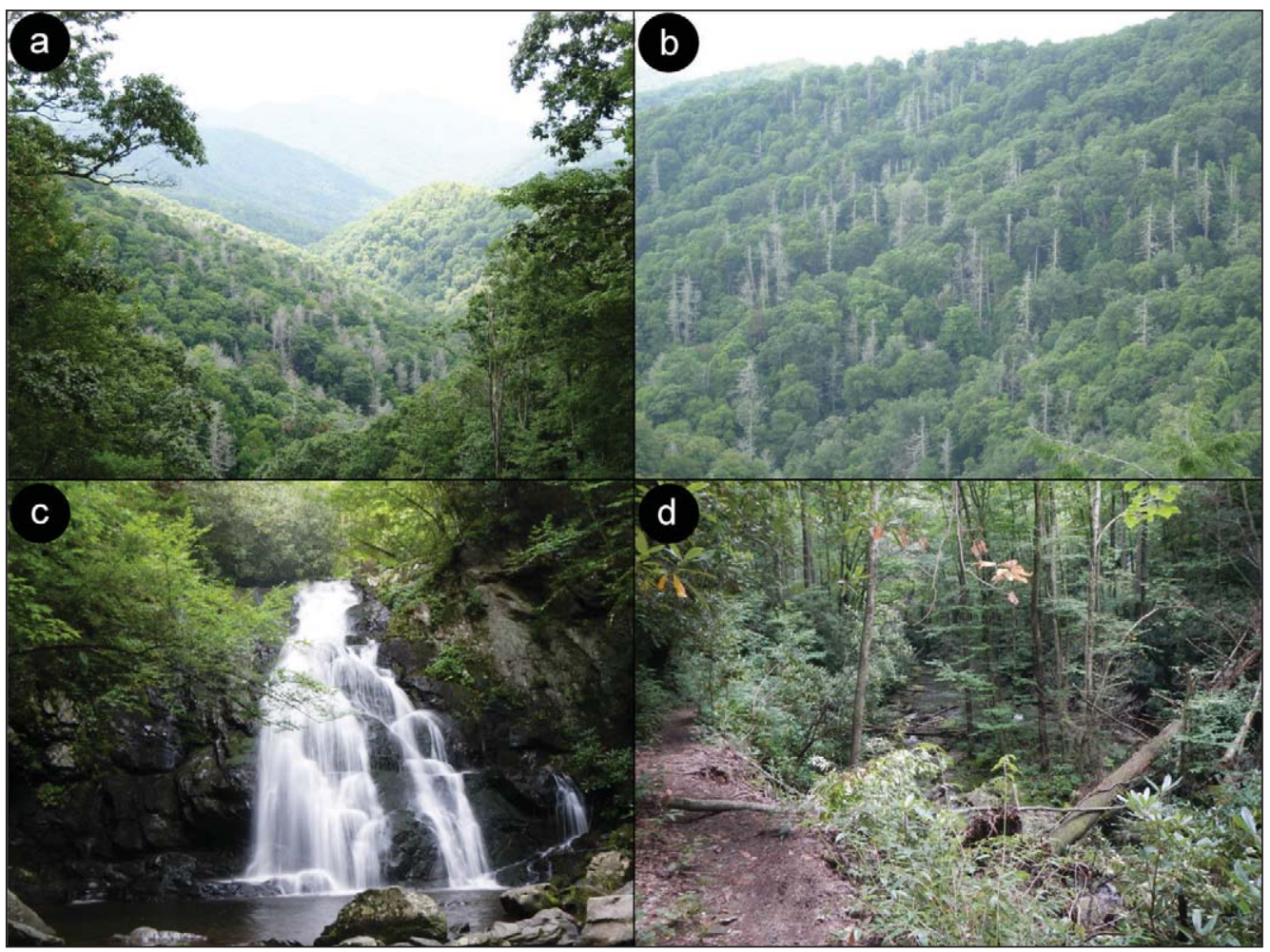

Figure. 1. a, b. View of mixed-species hillslope forest from afar and closer up with dead Eastern Hemlock (the gray dead trees) in Great Smoky Mountains National Park. Photo by S.R. Abella, 22 August 2013, along Highway 441 at 1200 m elevation near $35^{\circ} 35^{\prime} 44.9^{\prime \prime} \mathrm{N}$, $83^{\circ} 24^{\prime} 46.6^{\prime \prime W}$ (World Geodetic System 1984). c. Example of a typical site treated for Hemlock Woolly Adelgid within Great Smoky Mountains National Park to maintain Eastern Hemlock along riparian areas (photo by S.R. Abella, 21 August 2013). d. Trail damage from the death and toppling of an Eastern Hemlock, now lying across a stream in the bottom right of the photograph. Photo by S.R. Abella, 22 August 2013, near the Big East Fork Trailhead (Shining Rock Wilderness, Pisgah National Forest, NC), 1200 m elevation near $35^{\circ} 21^{\prime} 32^{\prime \prime} \mathrm{N}$, $82^{\circ} 49^{\prime} 43^{\prime \prime} \mathrm{W}$. 
found that snow depth was 50\% lower and minimum temperature averaged $2{ }^{\circ} \mathrm{C}$ warmer in Eastern Hemlock forests than hardwood forests. Eastern Hemlock also influences stream flow, stream water temperature, water chemistry, and light availability for aquatic ecosystems differently than hardwood forests that also occupy riparian areas (Ford and Vose 2007, Snyder et al. 2002). Comparative research to clarify Eastern Hemlock's functional role in watersheds, and whether these functions vary among regions, is accumulating (e.g., Jenkins et al. 1999, Siderhurst et al. 2010).

Several studies suggest that soil properties below Eastern Hemlock differ from those below eastern hardwoods. Compared to five hardwood tree species in Connecticut, for example, Finzi et al. (1998) reported that soil below individual Eastern Hemlock trees exhibited elevated $\mathrm{O}$ horizon mass, $\mathrm{C}$ content, and $\mathrm{N}$ content, while pH was lower. Similarly, at a more southerly location in Kentucky, Boettcher and Kalisz (1990) reported that O horizon mass was greatest below Eastern Hemlock while the $\mathrm{pH}$ of the $\mathrm{O}$ horizon and $0-5 \mathrm{~cm}$ mineral soil layer was low. Likely due in part to acidic litter with a high $\mathrm{C}: \mathrm{N}$ ratio, decomposition and $\mathrm{N}$ mineralization below Eastern Hemlock can be slow (Boettcher and Kalisz 1990, Finzi et al. 1998). Unique soil properties below Eastern Hemlock are thought to influence understory plant species composition (Beatty 1984).

Eastern Hemlock forests support a unique assemblage of understory plants, and total understory cover is low unless dominant, shade-tolerant shrubs such as Rhododendron spp. (azalea, laurel) are present. In the southern Appalachians, for example, species such as Hexastylis shuttleworthii (Britten and Baker f.) Small (Largeflower Heartleaf), Mitchella repens L. (Partridgeberry), and Leucothoe fontanesiana (Steud.) Sleumer (Highland Doghobble) were more important in

Table 1. Functions of Eastern Hemlock within ecosystems and for humans.

Function

Examples

Microclimate creation All-year low-light environment; moderate temperature extremes

Soil protection

Nutrient retention

Carbon sequestration

Watershed value

Fish habitat

Invertebrate habitat

Wildlife habitat

Plant habitat

Community diversity

Aesthetics

Recreation
Thick O horizons overlay mineral soil

Acidic, decomposition-resistant, high $\mathrm{C}: \mathrm{N}$ litter

High biomass; high $\mathrm{O}$ horizon $\mathrm{C}$ content

Shaded stream environment; coarse woody debris production

Unique in-stream insect and fish composition

Unique communities; some species prefer Eastern Hemlock

96 bird, 47 mammal species associates of Eastern Hemlock in Northeast

Unique composition often with evergreen plants Increased within-landscape richness of biological communities

Evergreen trees valued for their appearance

Hemlock location near water; ameliorated microclimate
Example reference

Webster et al. 2012

Beatty 1984

Orwig et al. 2008

Finzi et al. 1998

Siderhurst et al. 2010

Ross et al. 2003

Ingwell et al. 2012

Yamasaki et al. 2000

Abella and Shelburne 2004

Jenkins 2007

Ellison et al. 2005

Quimby 1996 
Eastern Hemlock forests than anywhere else on the landscape (Abella and Shelburne 2004). Rhododendron maximum L. (Great Rhododendron), a large evergreen shrub, often dominates understories of Eastern Hemlock forests in the South. In northern forests, Rogers (1980) concluded that understories of Eastern Hemlock forests exhibited significant regional variation and were structurally unique within landscapes. Eastern Hemlock forest understories contained abundant woody plants (especially tree seedlings), evergreen plants, and ferns (Rogers 1980).

Eastern Hemlock contributes to landscape-scale wildlife diversity in at least three ways by supporting: (i) some species largely restricted to Eastern Hemlock forests, (ii) some species associated with other habitats but present in Eastern Hemlock forests, and (iii) unique wildlife assemblages contributing to overall diversity within landscapes (Ross et al. 2004, Yamasaki et al. 2000). In Wisconsin, for instance, Howe and Mossman (1995) found that the bird species Dendroica fusca Müller (Blackburnian Warbler) and Troglodytes troglodytes Vieillot (Winter Wren) were three times as frequent in Eastern Hemlock as in hardwood forests. Yamasaki et al. (2000) noted that 96 bird and 47 mammal species were associated with Eastern Hemlock forests in northeastern states.

Eastern Hemlock provides numerous benefits to humans both inside and outside park settings. Many ecological functions provided by Eastern Hemlock, such as watershed functions, are also important to humans. Although timber production is not a goal in parks, Eastern Hemlock was a source of timber and tannins in the past, and pre-emptive logging of Eastern Hemlock on non-park lands before HWAinduced mortality is an important contemporary issue (Kizlinski et al. 2002). While ecological tradeoffs characterize pre-emptive logging, Eastern Hemlock is at least temporarily providing lumber on some lands (Orwig et al. 2012). Partly because of their frequent occurrence near streams, Eastern Hemlock forests are areas of human recreation and valued for aesthetics (Quimby 1996).

\section{HWA Autecology and Dynamics}

HWA is a small $(<1.5 \mathrm{~mm}$ long), aphid-like insect that is reddish-brown to purplish-black in color. Its name comes from its woolly white appearance, which develops as it matures and produces a covering of wool-like wax filaments to protect its eggs. HWA is considered native to Japan where it inhabits forests containing Tsuga sieboldii Carr. (Southern Japanese Hemlock; Havill et al. 2011). The insect is considered a relatively innocuous component in its native range where, apparently, its population is kept low by host resistance and natural enemies. In Connecticut, McClure (1996) described three annual HWA generations: an overwintering generation and two types of spring generations. All generations have six stages of development: egg, four nymphal instars, and adult. These generations have different developmental timing within a year (Havill et al. 2011). The largest adults average $1.4 \mathrm{~mm}$ long and $1.1 \mathrm{~mm}$ wide (McClure 1996). HWA kills Eastern Hemlock by sucking sap and depleting the tree of starch reserves (Havill and Foottit 2007, Jonas et al. 2012).

Souto et al. (1996) noted that HWA was first reported in the eastern US in the early 1950s, near Richmond, VA. From the mid-1950s to mid-1980s, HWA 
spread slowly through the mid-Atlantic states and was considered a pest only to ornamental trees in urban environments and readily controllable using insecticides (Souto et al. 1996). However, potentially aided by spread from a 1985 hurricane, HWA continued dispersing to reach extensive natural stands of Eastern Hemlock, and damage to Eastern Hemlock forests began increasing exponentially. As Havill et al. (2011) summarized, HWA has not co-evolved with eastern North American forest ecosystems, and as a result, Eastern Hemlock cannot resist or tolerate HWA feeding, and the native community of natural enemies cannot keep HWA populations below damaging levels.

Temperature appears important in HWA population dynamics and spread (Paradis et al. 2008). Major declines in HWA populations in eastern North America have followed cold years, but populations subsequently rebounded. HWA's northern spread also seems temperature-limited. McClure (1996) noted that HWAs introduced to eastern North America were apparently from a non-cold-hardy strain, because Japan has some other HWA populations that persist at low temperatures. Climatic warming could accelerate HWA's movement northward, but it should not be assumed that warming is needed for this to occur because of potential adaptive ability of HWA in the current climate (Butin et al. 2005). Morin et al. (2009) reported that HWA has spread at an average rate of 9-20 km/year, and they further noted that faster spread can occur through long-distance transport such as by humans inadvertently moving infested material.

\section{National Parks Impacted by HWA}

Eighty-five parks, or $21 \%$ of the 401 parks in the US NPS system, are within the range of Eastern Hemlock (Fig. 2). Parks within Eastern Hemlock's range include significant American natural and cultural features such as in Valley Forge National Historical Park, King of Prussia, PA; Antietam National Battlefield, Sharpsburg, MD; Gettysburg National Military Park, Gettysburg, PA; Hopewell Culture National Historical Park, Chillicothe, OH; Appalachian National Scenic Trail (GA-ME); and in the largest eastern parks including Great Smoky Mountains National Park (GSMNP), Gatlinburg, TN; Shenandoah National Park, Luray, VA; Sleeping Bear Dunes National Lakeshore, Empire, MI; and Acadia National Park, Bar Harbor, ME. Based on 2011-2012 HWA distribution maps, HWA had not spread into northern Maine and was not reported in Acadia National Park (Harris et al. 2012), was absent from the upper Great Lakes including parks in Michigan and Wisconsin, and had not reached disjunct Eastern Hemlock populations in western Kentucky in Mammoth Cave National Park, Mammoth Cave, KY (US Forest Service, Forest Health Technology Enterprise Team, http://foresthealth.fs.usda.gov/portal).

Some isolated populations of Eastern Hemlock exist in western Georgia, Kentucky, and Indiana, which include some national park units such as Mammoth Cave National Park (Fig. 2). The disjunct populations might afford some opportunity to attempt limiting establishment of HWA within these isolated areas through prevention, early detection, and treatment of any incipient HWA populations (Hart 2008, Koch et al. 2006). 
Table 2 lists 16 parks that exceed 2000 ha and contain Eastern Hemlock, with 10 of these parks - all but those in the Great Lakes, northern Maine, and western Kentucky - reporting presence of HWA. Excluding Appalachian National Scenic Trail for which records were not available, the 15 other parks have received a combined visitation of 45 million people annually from 2008-2012 (Public Use Statistics Office, NPS, Denver, CO). Based on vegetation maps available for 10 of the parks (NPS, Vegetation Inventory Program, Fort Collins, CO) and a fire vegetation map for Big South Fork National River and Recreation Area, Oneida, TN, pure Eastern Hemlock forests or mixed-species forests with Eastern Hemlock occupy about $2-26 \%$ of park area (Table 2). Thus, there are parks such as Mammoth Cave National Park in which Eastern Hemlock forests are locally rare, unique communities and parks such as GSMNP in which Eastern Hemlock forms a dominant part of total forest cover. Overall, for the 11 parks with vegetation maps, the combined Eastern Hemlock forest resource exceeds 60,000 ha.

\section{Impacts in Parks}

Eastern Hemlock mortality after HWA infestation can be rapid and pervasive (Ford et al. 2012). There is some encouraging recent information, however, that Eastern Hemlock mortality can be a slower process in some situations, at least in

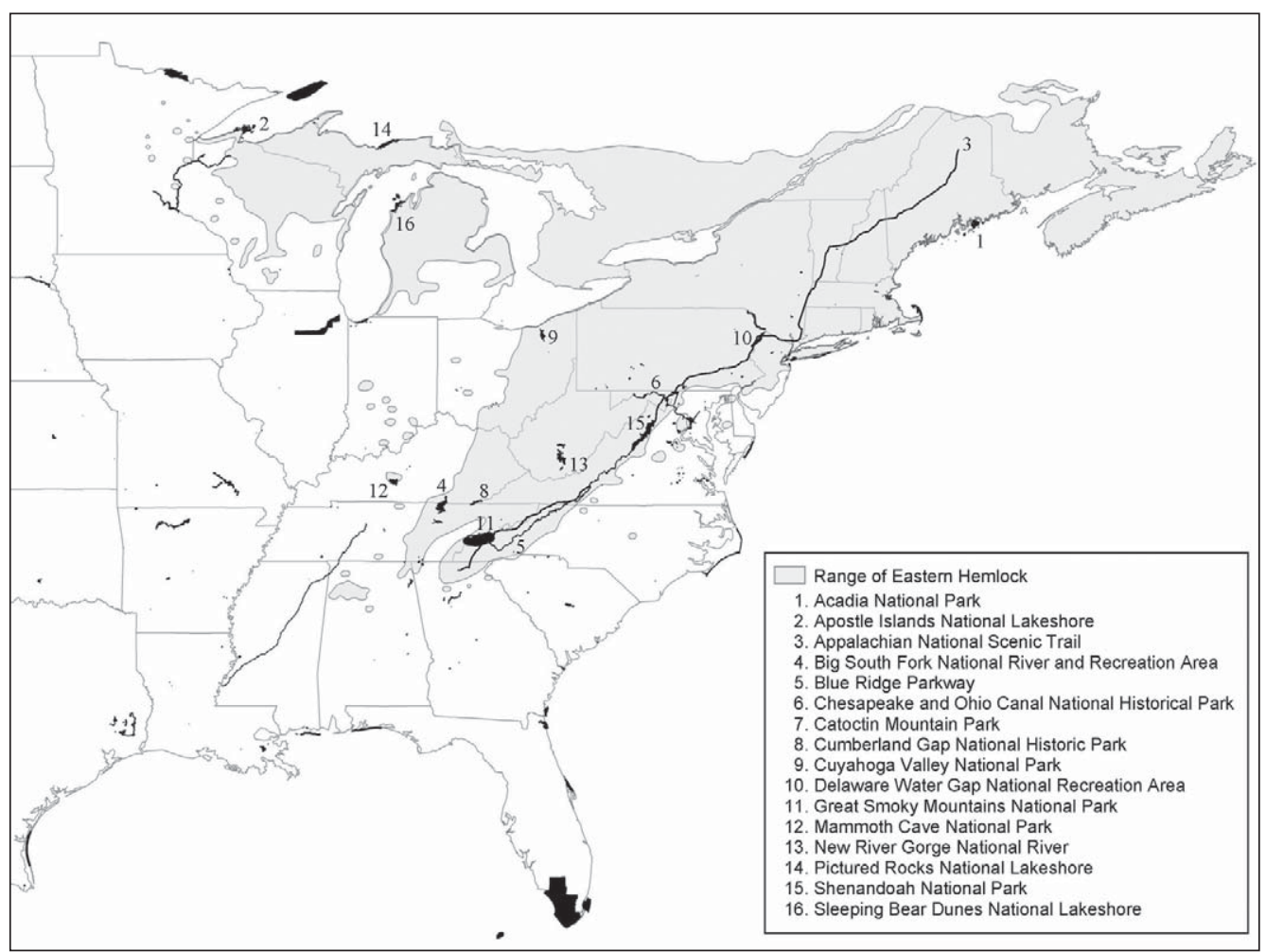

Figure 2. Range of Eastern Hemlock corresponding with distribution of National Park Service units (shown in black). Sixteen parks exceeding 2000 ha in size and within Eastern Hemlock's range are numbered according to the legend. 
northern areas, than was previously thought (Eschtruth et al. 2013, Orwig et al. 2012). Long-term monitoring in Delaware Water Gap National Recreation Area (DWGNRA) in NJ/PA revealed that $65 \%$ of infested Eastern Hemlock trees originally monitored in 1993 remained alive 20 years later in 2012 (Eschtruth et al. 2013). Mortality in both northern (Orwig et al. 2002) and southern regions (Martin and Goebel 2012) is thought to occur most quickly and be most extensive on dry sites where Eastern Hemlock trees are stressed. Duration of HWA infestation, however, can overwhelm importance of other site factors that influence the health of Eastern Hemlock forests (Martin and Goebel 2012, Rentch et al. 2009). Droughts seem to be associated with rapid HWA-induced Eastern Hemlock mortality, e.g., the rapid mortality (often $<4$ years) recorded in GSMNP during a mid-2000s dry period (J. Webster, GSMNP, Gatlinburg, TN, pers. comm.). Our current understanding suggests that Eastern Hemlock mortality rates partly depend on site and climatic conditions and can be rapid (within a few years) or slow over a period of decades. Recent findings also suggest that further research to clarify site and climatic factors affecting Eastern Hemlock mortality patterns is warranted to help prioritize HWA management treatments (Eschtruth et al. 2013, Martin and Goebel 2012, Rentch et al. 2009). It should be noted that these recent studies indicate that while slowed mortality at least in some cases is encouraging, the total mortality

Table 2. National Park Service units exceeding 2000 ha containing Eastern Hemlock forests. NP = National Park, NL = National Lakeshore, NR = National River, NHP $=$ National Historic Park, and NRA $=$ National Recreation Area.

\begin{tabular}{|c|c|c|c|c|c|}
\hline & States & Size (ha) & Hemlock ha $(\%)^{\mathrm{A}}$ & Polygons $(\%)^{\mathrm{A}}$ & Adelgid $^{\mathrm{B}}$ \\
\hline Acadia NP & ME & 14,473 & $2332(6.8)$ & $302(6.2)$ & \\
\hline Apostle Islands NL & WI & 17,062 & $1382(4.8)$ & $733(15.1)$ & \\
\hline $\begin{array}{l}\text { Appalachian National } \\
\text { Scenic Trail }\end{array}$ & ME to GA & 42,853 & - & - & $x$ \\
\hline Big South Fork NR and NRA & $\mathrm{KY} / \mathrm{TN}$ & 47,070 & $11,942(24.1)$ & - & $x$ \\
\hline Blue Ridge Parkway & $\mathrm{NC} / \mathrm{VA}$ & 33,272 & - & - & $x$ \\
\hline $\begin{array}{l}\text { Chesapeake and Ohio } \\
\text { Canal NHP }\end{array}$ & $\mathrm{MD} / \mathrm{DC} / \mathrm{WV}$ & 5325 & - & - & $x$ \\
\hline Catoctin Mountain Park & MD & 2384 & - & - & $x$ \\
\hline Cumberland Gap NHP & $\mathrm{KY} / \mathrm{TN} / \mathrm{VA}$ & 9852 & $166(2.0)$ & $38(1.7)$ & $x$ \\
\hline Cuyahoga Valley NP & $\mathrm{OH}$ & 7697 & - & - & \\
\hline Delaware Water Gap NRA & $\mathrm{NJ} / \mathrm{PA}$ & 22,761 & $3233(11.6)$ & $316(6.7)$ & $x$ \\
\hline Great Smoky Mountains NP & $\mathrm{TN} / \mathrm{NC}$ & 211,219 & $57,106(26.0)^{\mathrm{C}}$ & $11,604(23.2)^{\mathrm{C}}$ & $x$ \\
\hline Mammoth Cave NP & KY & 21,045 & $262(1.3)$ & $73(0.9)$ & \\
\hline New River Gorge NR & WV & 21,687 & $1339(4.6)$ & $855(10.3)$ & $x$ \\
\hline Pictured Rocks NL & MI & 14,434 & $2157(6.4)$ & $516(10.7)$ & \\
\hline Shenandoah NP & VA & 79,904 & $1903(2.4)$ & - & $x$ \\
\hline Sleeping Bear Dunes NL & MI & 22,953 & $687(2.0)$ & $443(4.8)$ & \\
\hline \multicolumn{6}{|c|}{$\begin{array}{l}\text { A Vegetation mapping could include a buffer area surrounding parks, and the percentage of Eastern } \\
\text { Hemlock area and number of polygons was calculated based on the total area of mapped vegetation. } \\
(-) \text { indicates mapping is not complete. } \\
{ }^{\mathrm{B}} \text { Symbols }(\times) \text { indicate Hemlock Woolly Adelgid is present within a park as of } 2012 \text {. } \\
{ }^{\mathrm{C}} \text { Amount of pure Eastern Hemlock forest approximates } 6381 \mathrm{ha} \text {, or } 2.9 \% \text { of the park. }\end{array}$} \\
\hline
\end{tabular}


is frequently extensive, and that trees weakened by HWA are susceptible to other pests, windthrow, and other mortality-causing agents. Additionally, dieback of Eastern Hemlock tree crowns, even when trees have not died, can have ecological effects due to changes in light availability and other factors (Eschtruth et al. 2013).

Research regarding existing and projected HWA impacts has been published for four NPS units currently infested by HWA (Table 3). Available research on impacts to vegetation, fungi, watersheds, fisheries, wildlife, and invertebrates, is summarized in the following sections for DWGNRA (NJ/PA), GSMNP (NC/TN), Shenandoah National Park (VA), and New River Gorge National River (WV) to illustrate types of impacts to parks and their broad geographic extent.

\section{Delaware Water Gap National Recreation Area}

HWA was detected in DWGNRA in 1989, and the park has the longest-term, most extensively reported monitoring of HWA infestation, Eastern Hemlock decline, and

Table 3. Examples of impacts or potential impacts to Eastern Hemlock ecosystems from Hemlock Woolly Adelgid reported from National Park Service units.

National Park Service unit/HWA-impact reports

Delaware Water Gap National Recreation Area

Four bird species at risk strongly associated with Eastern Hemlock

Fewer breeding Acadian Flycatchers in HWA-infested sites

Bryophyte cover doubled after HWA infestation

Understory plant cover doubled; tree seedling changes variable

Interaction between HWA and deer influence tree changes

Increased invasion of exotic plants in Adelgid sites

Overview of numerous past and present ecosystem changes

Native Brook Trout had $3 \times$ abundance in Eastern Hemlock than hardwood streams

Aquatic invertebrates differed between Eastern Hemlock and hardwood streams

Great Smoky Mountains National Park

Unique fungal communities associated with Eastern Hemlock, including species new to science

Both Adelgid and chemical treatments for HWA can affect insects and birds

Evergreen shrub Great Rhododendron might affect tree and understory plant changes

In-stream light increased overall, but Great Rhododendron could mollify aquatic changes

Shenandoah National Park

Overall arthropod abundance could increase but at expense of Eastern Hemlock-associated species

Eastern Hemlock crown condition declines from $80 \%$ healthy trees in 1990 to near $0 \%$ in 2000

New River Gorge National River

Uncertain future forest composition because of disease afflicting other tree species
Reference

Ross et al. (2004)

Allen et al. (2009)

Cleavitt et al. (2008)

Eschtruth et al. (2006)

Eschtruth and Battles (2008)

Eschtruth and Battles (2009)

Evans (2010)

Ross et al. (2003)

Snyder et al. (2002)

Baird et al. $(2007,2009)$

Falcone and DeWald (2010)

Krapfl et al. $(2011,2012)$

Roberts et al. (2009)

Rohr et al. (2009)

Willeford Bair (2002)

Martin and Goebel (2012) 
consequent ecological impacts in the national park system (Evans 2010). Evans et al. (1996) provided an early projection of anticipated HWA impacts: gap infilling by tree species such as Betula alleghaniensis Britton (Yellow Birch) and Acer rubrum L. (Red Maple), reduced bryophyte abundance, increased overall abundance of understory plants including more exotic plants, increased soil $\mathrm{N}$ availability, increased understory and stream light levels and temperatures, reduced populations of native Salvelinus fontinalis Mitchill (Brook Trout), and reduced populations of birds strongly associated with Eastern Hemlock. Subsequent studies allow evaluation of some of these projected impacts.

Effects of HWA on vegetation in DWGNRA have been significant. Eschtruth et al. (2006) reported on changes from 1994 (pre-HWA) to 2003, with major Eastern Hemlock mortality beginning before 1999. In 1994, over 95\% of Eastern Hemlock trees at Adams Creek within the park had healthy crown-vigor ratings, but only 9 years later in $2003,<35 \%$ of trees were healthy, and the rest were either declining $(45 \%)$ or already dead $(20 \%)$. Light transmission to the understory more than doubled from 1994-2003, supporting the prediction that forest light-levels would increase. Note that while light likely decreased as other trees filled in the gaps, this reduction would only be appreciable during the leaf-on growing season because these tree species were deciduous. Understory-tree relative density changes were difficult to discern, as Fagus grandifolia Ehrh. (American Beech) increased by four-fold at one site but not another, and relative density of other species such as Red Maple and Betula lenta L. (Sweet Birch) changed little. As Evans et al. (1996) predicted, overall understory plant cover more than doubled from 1994-2003, but remained below 17\%. Future tree species composition of former Eastern Hemlock forests is difficult to predict because of the numerous factors that can affect tree establishment. For example, Odocoileus virginianus Zimmermann (White-Tailed Deer) density exceeds 20 animals $/ \mathrm{km}^{2}$ in DWGNRA, and these animals can dramatically influence forest change following Eastern Hemlock decline (Eschtruth and Battles 2008).

Some studies have not supported the prediction that native bryophyte abundance would decline but have supported the prediction that exotic plant cover would increase post-HWA. Cleavitt et al. (2008) reported that bryophyte cover doubled from 1994 (pre-HWA) to 2006 (about 7 years post-HWA), with increases in species such as Dicranum montanum Hedw. (Montane Dicranum Moss) and Brachythecium rutabulum (Hedw.) Schimp. (Brachythecium Moss), as well as species associated with coarse woody debris. Cleavitt et al. (2008) further noted uncertainty about how long bryophytes might continue to increase, and discussed factors such as establishment of hardwood trees and shrubs that could affect future bryophyte composition. Eschtruth and Battles (2009) found that exotic plants increased with light availability following Eastern Hemlock mortality. Moreover, White-Tailed Deer herbivory interacted with Eastern Hemlock mortality to further increase exotic plants while decreasing native plants. The priority exotic plants Alliaria petiolata (M. Bieb.) Cavara and Grande (Garlic Mustard), Berberis thunbergii DC. (Japanese Barberry), and 
Microstegium vimineum (Trin.) A. Camus (Nepalese Browntop) all increased outside of exclosures open to deer herbivory in HWA-affected forests.

Snyder et al. (2002) and Ross et al. (2003) highlighted potential HWA impacts to watershed functions and aquatic ecosystems in the park. Snyder et al. (2002) found that aquatic invertebrate composition was strongly correlated with forest composition (Eastern Hemlock versus hardwood forests). Streams draining Eastern Hemlock forests had $8 \%$ of their aquatic taxa strongly associated with Eastern Hemlock, and species evenness (one component of diversity) was higher in streams running through Eastern Hemlock than hardwood forests. The authors concluded that declines in Eastern Hemlock indicated potential for reductions in within-stream and park-wide benthic diversity. Ross et al. (2003) found that native Brook Trout were three times as prevalent in Eastern Hemlock as in hardwood forest streams. Fish species richness did not differ between Eastern Hemlock and hardwood forest streams, suggesting that changes might be mostly compositional.

Two studies in the park have examined relationships of bird species with Eastern Hemlock forests. Ross et al. (2004) reported that bird species richness was greater in hardwoods than in Eastern Hemlock forests, but four bird species strongly associated with Eastern Hemlock were at risk. These four were insectivorous species including Empidonax virescens Vieillot (Acadian Flycatcher), Vireo solitarius Wilson (Blue-Headed Vireo), Dendroica virens Gmelin (Black-Throated Green Warbler), and Dendroica fusca Müller (Blackburnian Warbler). Allen et al. (2009) further compared abundance of Acadian Flycatcher across sites representing a gradient of Eastern Hemlock mortality. Eastern Hemlock supported $90 \%$ of nests of this species, and 70\% fewer breeding pairs occupied HWA-infested sites. These studies, combined with those on other lands (Becker et al. 2008, Tingley et al. 2002), suggest that while some bird species might benefit from Eastern Hemlock mortality, Hemlock-associated species such as the Acadian Flycatcher have declined. These species will likely decline further unless they adapt to changing habitat conditions.

\section{Great Smoky Mountains National Park}

HWA was first identified in GSMNP in 2002 (Lambdin et al. 2006), and potentially because of the park's southerly location and subsequent drought, Eastern Hemlock trees died rapidly, often within a few years of HWA infestation (Ford et al. 2012). Krapfl et al. $(2011,2012)$ measured 32 plots established in the park in 2003 before full HWA infestation and resampled the plots in 2008-2009 when all plots contained HWA. By the 5-year post-HWA measurement, Eastern Hemlock overstory and understory tree density declined. Similar to results from DWGNRA (Eschtruth et al. 2006), only 20\% of overstory Eastern Hemlock had good crowncondition ratings, with the remaining trees dead or severely declining. Overstory tree species composition ( 44 species, mostly hardwoods, on all plots) and understory tree and tall-shrub composition ( 79 species) were species-rich, but no difference existed in relative stem density (excluding Eastern Hemlock) of species between 2003 and 2008/2009. The authors hypothesized that in many areas, future species composition might hinge upon responses of the dominant native, evergreen shrub 
Great Rhododendron, which might partly buffer changes in light transmission to the forest floor from Eastern Hemlock die off (Krapfl et al. 2012).

Fungi were compared among tree species and between HWA-damaged and healthy bark of Eastern Hemlock trees by Baird et al. (2007, 2009). Microfungal assemblages did not differ between damaged and healthy bark within $\approx 1-2$ years of HWA infestation. A rare fungus, Thysanophora canadensis Stolk and Hennebert, occurred only on Eastern Hemlock, raising the possibility that this fungal species is at risk from Eastern Hemlock mortality (Baird et al. 2007). With over 55 fungal species new to the park discovered in 2005-2006 during an All Taxa Biodiversity Inventory, the possibility exists that numerous little-known organisms such as fungi might be impacted by HWA before we even know the species exist in parks (Baird et al. 2009).

Falcone and DeWald (2010) compared arthropods and insectivorous birds between HWA-infested Eastern Hemlock stands treated with insecticide for two years and untreated HWA-infested stands. The study did not detect differences in total arthropod abundance or density of insectivorous birds between ongoing treatment areas and untreated stands. However, herbivorous Hemiptera and larval Lepidoptera were significantly lower in treated stands. This illustrated the potential for non-target treatment effects (Falcone and DeWald 2010) and a difficulty in evaluating impacts of both HWA and counter-treatments: lack of unaffected Eastern Hemlock reference sites for comparison.

Roberts et al. (2009) compared characteristics of streams in the park flowing through paired Eastern Hemlock and hardwood forests to project potential changes if hardwoods replaced Eastern Hemlock. Unlike studies elsewhere, little relationship between forest type and stream characteristics of discharge, water temperature, $\mathrm{pH}$, and $\mathrm{NO}_{3}-\mathrm{N}$ concentration was evident over a one-year period. There were some differences in light levels (mainly during the leaf-off period of deciduous trees), but presence of Great Rhododendron moderated differences. Light levels in hardwood forests with Great Rhododendron understories resembled light levels of streams in Eastern Hemlock forests. Their study, combined with Krapfl et al. (2012), suggested that Great Rhododendron dynamics might influence numerous changes after Eastern Hemlock trees die within parks.

\section{Shenandoah National Park}

Willeford Bair (2002) described networks of plots established in 1990 and 1999 to monitor the condition of Eastern Hemlock trees. From 1990-2000, the percentage of Eastern Hemlock trees in the excellent crown-condition class dropped sharply from $80 \%$ to near zero, with $49 \%$ mortality. While Eastern Hemlock trees at higher elevations were still impacted by HWA, crown condition on average was twice as good at elevations above $750 \mathrm{~m}$ than below. This finding was consistent with observations that HWA populations currently seem limited by cold temperatures (Morin et al. 2009). Willeford Bair (2002) made the important point that other factors being equal, high-elevation Eastern Hemlock populations may warrant special attention for preventive HWA management. 
Another study in the park compared arthropod assemblages in Eastern Hemlock stands with those in hardwood forests that might replace the former. Rohr et al. (2009) concluded that Eastern Hemlock loss might increase overall arthropod abundance, including increased abundance for 23 arthropod taxa, while overall species richness, including 7 taxa strongly associated with Eastern Hemlock, could decline.

\section{New River Gorge National River}

Martin and Goebel (2012) used a 9- to 32-year chronosequence of time-sinceinvasion of HWA to evaluate dynamics in Eastern Hemlock forests in West Virginia and Virginia riparian areas, including along the New River. As Willeford Bair (2002) found, Eastern Hemlock decline was moderated at the highest elevations and in topographic positions with the coolest temperatures, but time since invasion of HWA was the primary factor in Hemlock decline. The authors concluded that relatively slow decline of Eastern Hemlock stands over a period of years to decades characterizes this park, similar to DWGNRA, and that while elevation or topography may initially slow the decline, duration of HWA infestation eventually predominates the dynamics of infestation. Based on the finding that saplings and seedlings were at least as rapidly affected as canopy trees, the authors projected essentially complete mortality of all Eastern Hemlock size classes (Martin and Goebel 2012). The authors also expressed uncertainty about future forest composition because composition could be contingent upon numerous factors, including presence of the exotic, competitive tree Ailanthus altissima (Mill.) Swingle (Tree of Heaven), which comprised over 50\% relative basal area at some sites. Moreover, American Beech, a shade-tolerant potential replacement tree, also is under stress from infection with the introduced Beech Bark Disease.

\section{Synthesis of impacts}

Understanding HWA impacts within national parks and on other lands surrounding parks is important for at least two reasons: connectedness of park ecosystems with those of adjacent land (e.g., HWA spread, dispersion of biocontrol species into and out of parks, and watershed connectivity), and the potential to extrapolate what is learned on other lands and in parks, and apply it in the other. Research regarding HWA impacts in national parks is generally consistent with research conducted on other lands, and the collective literature has suggested several general principles related to HWA impacts: (1) Cold temperature appears to limit HWA distribution, and while warming temperatures might expedite HWA's spread, it should not be assumed that warming is needed for the continued spread of the infestation given HWA's apparent adaptive capacity (Butin et al. 2005, Paradis et al. 2008); (2) All size classes of Eastern Hemlock trees have been killed by HWA, and while searching for potentially resistant trees is warranted, resistance appears low to non-existent (Vose et al. 2013); (3) Eastern Hemlock mortality might be fastest in warmer regions, but in non-drought periods, mortality at a stand scale might still occur over a period of years to decades (Ford et al. 2012); (4) HWA increases abundance of dead wood, which can have numerous effects on ecosystems (e.g., soil nutrient cycling, input of wood to streams) and create hazard trees at human-use sites (Evans and Shreiner 2008); 
(5) There likely will be short-term impacts immediately following Eastern Hemlock mortality (e.g., increased light) and longer-term impacts likely contingent upon postinfestation vegetation dynamics (Small et al. 2005); (6) Many impacts of Eastern Hemlock mortality to ecosystem functions likely depend on post-infestation forest structure and which resulting forest communities become established (Farnsworth et al. 2012); (7) Tree species and vegetation that may replace Eastern Hemlock forests are difficult to predict (Orwig et al. 2012); (8) Colonizing vegetation will likely be controlled by numerous factors, such as damaging agents (e.g., exotic pests) affecting potential tree species replacements, White-Tailed Deer herbivory, invasion of exotic plants, and dynamics of competitive native plant species such as Great Rhododendron (Eschtruth et al. 2006); (9) Impacts to ecosystem functions and variability in colonizing vegetation within landscapes and among regions will likely be substantial (Evans et al. 2011); (10) As with many ecological events, some species will benefit from Eastern Hemlock mortality. Species associated with Eastern Hemlock must adapt or decline, and Hemlock loss will reduce species diversity unless it triggers long-term speciation (Adkins and Rieske 2013 , Becker et al. 2008, Yorks et al. 2003); and (11) Further research to identify organisms strongly associated with Eastern Hemlock could help determine which species are most at risk from Hemlock loss (Baird et al. 2009).

Previous research has also further described specific ecological impacts of Eastern Hemlock mortality: (1) Microclimate changes are projected and there will be greater variation in temperature and light with loss of Hemlock's ameliorating influence, and more light will reach the forest floor, although this effect could be partly offset if other evergreen species increase (Webster et al. 2012); (2) Nutrient cycling will probably change, likely with altered soil organic matter pools and increased N mineralization and nitrification (Stadler et al. 2006); (3) Several comparisons exist of stream and fishery characteristics between Eastern Hemlock forests and potential replacement hardwood forests (e.g., Ross et al. 2003), but actual impacts likely will remain uncertain until longer-term post-Hemlock assessments are available, including those that have encompassed the effects of major storm events (Siderhurst et al. 2010). Based on existing work, impacts to post-infestation stream characteristics might not be dramatic at every site, especially when other evergreen plants colonize those formerly covered by Eastern Hemlock (Roberts et al. 2009); (4) Understory plant cover and species richness have increased after Eastern Hemlock mortality. However, exotic plant invasion also increases on sites that formerly supported Hemlock stands (Eschtruth and Battles 2009); and (5) Changes in wildlife and invertebrate species composition largely appear to have hinged upon interaction between species favoring Eastern Hemlock and those that do not favor habitat conditions created by Hemlock (Ingwell et al. 2012).

\section{National Park Management}

Results from studies of HWA invasion highlight challenges that the NPS will increasingly face from introduced forest pests, including in key policy areas such as biocontrol and facilitating park adaptation to ecological change. Moreover, Vose 
et al.'s (2013) review of potential HWA management actions, largely geared to non-park lands, is useful for illuminating some aspects unique to managing a forest die-off event in a national park context. A range of potential strategies to reduce undesired impacts of HWA to parks warrants consideration (Table 4).

\section{Collect genetic material}

Resistance of Eastern Hemlock trees to HWA seems minimal (Orwig et al. 2002). Nevertheless, surveys for potentially resistant trees are warranted within parks, especially considering that pre-emptive salvage logging is not a goal in parks. Preemptive logging has occurred on private lands, and while this can generate revenue for landowners, it reduces the possibility of identifying resistant trees if any population or individual-tree resistance happens to occur (Kizlinski et al. 2002). Ingwell and Preisser (2011) described a citizen-science program in which volunteers survey for potentially resistant Eastern Hemlock trees, and the authors suggested that some trees showed resistance to adult HWA. This type of volunteer program can be highly applicable in a national park context and is usually a low-cost tool if the only park commitment is to provide coordination and training (Ingwell and Preisser 2011). Regardless of whether there are HWA-resistant Eastern Hemlocks, collection of genetic material from parks is warranted so that material is available for resistance breeding programs and for Eastern Hemlock restoration if HWA can be controlled (Jetton et al. 2010). American Chestnut represents an example of an ongoing program to breed resistance to an introduced damaging agent and illustrates advantages and disadvantages of such programs. Trees with genotypes similar to the original wild type are available for test field-plantings, but their genetics have been altered from the original species, and reintroduction of these trees might displace native tree species that have partly replaced American Chestnut (Jacobs 2007). With due consideration to these tradeoffs, current NPS policy allows flexibility in supporting breeding programs to introduce resistant trees (NPS 2006).

\section{Chemical treatment}

Chemical treatments have served to keep individual trees or small stands of Eastern Hemlock alive, and their use requires balancing negative, non-target effects

Table 4. Summary of preventive, adaptive, and restorative strategies for Eastern Hemlock forests impacted by Hemlock Woolly Adelgid in a National Park Service context.

\begin{tabular}{ll} 
Activity & Example reference \\
\hline Constrain HWA spread to disjuncts & Hart (2008) \\
Biocontrol & Havill et al. (2012) \\
Chemical control & Cowles (2009) \\
Manage deer density & Eschtruth and Battles (2009) \\
Control exotic plants & Evans and Shreiner (2008) \\
Reduce other stressors & Ellison et al. (2005) \\
Promote replacement vegetation & Vose et al. (2013) \\
Limit replacement tree die off & Small et al. (2005) \\
Collect genetic material & Jetton et al. (2010) \\
Protect public from hazard trees & Johnson et al. (2008) \\
\hline
\end{tabular}


of the treatment and its financial cost versus consequences of losing the trees (Knoepp et al. 2012). The insecticide imidacloprid is a recommended chemical for HWA control. It is either applied to soil, injected into tree trunks, or applied as a foliar spray. Cowles et al. (2006) tested several trunk and soil applications on Eastern Hemlock trees in Connecticut and concluded that soil applications reduced HWA populations by $50-100 \%$ for $>2$ years, but no trunk injection-treatment significantly reduced HWA. Further research determined the minimum doses required and the optimal form (tablets versus powder) of soil-applied imidacloprid that would maximize efficacy for HWA control and minimize the potential for undesired transport to aquatic ecosystems (Cowles 2009). In the southern Appalachian Mountains, Knoepp et al. (2012) reported that horizontal movement of imidacloprid in soil was limited. They found that imidacloprid concentration at canopy drip lines was low compared to the concentration near trunks. Their study illustrated that elevation and soil organic matter (and potentially texture) can influence imidacloprid retention in soil among sites.

GSMNP is an example of a park that has aggressively treated HWA (Johnson et al. 2008, Webster 2010). The park has used imidacloprid to treat over 250,000 Eastern Hemlock trees since the early 2000s in prioritized areas such as along streams, trails, roads, and specially identified Eastern Hemlock conservation areas (K. Johnson and J. Webster, GSMNP, Gatlinburg, TN, pers. comm.). The park's treatment protocol has evolved over time, and the current preferred method is an aqueous soil drench of imidacloprid applied to the soil surface around trunks of trees (J. Webster, pers. comm.). For trees $<63 \mathrm{~cm}$ diameter at breast height (DBH), current chemical costs are $\$ 0.09 / 2.5 \mathrm{~cm} \mathrm{DBH}$ at a dose rate of $0.7 \mathrm{~g}$ active ingredient $/ 2.5 \mathrm{~cm}$ DBH. Trees $\geq 63 \mathrm{~cm}$ DBH are dosed at $1.4 \mathrm{~g}$ active ingredient $/ 2.5 \mathrm{~cm}$ DBH. A range of tree sizes (including small trees $<20 \mathrm{~cm} \mathrm{DBH}$ ) have been treated by soil drench to conserve forest structure. Effectiveness of an individual treatment now appears to last longer than previously thought. The park believes that treatments effectively control HWA for 5 years and possibly as long as 8 years before re-treatment is necessary to keep HWA populations low (J. Webster, pers. comm.). If water is unavailable at treatment sites, the park uses imidacloprid tablets placed in soil around tree trunks.

Countless untreated Eastern Hemlock trees have died throughout the GSMNP, and given limited resources for treatment, it is not feasible to treat all trees within the park. Park staff view chemical treatments as a way to maintain some priority Eastern Hemlock stands and as a strategy to buy time until other chemical or biocontrol treatments are developed, or other processes limit the spread and impact of HWA (K. Johnson and J. Webster, pers. comm.). In addition to continuing treatment of currently treated stands, the park is interested in assessing and treating some high-elevation Eastern Hemlock stands that occur above $1400 \mathrm{~m}$ (Webster 2010). HWA populations might be limited by cold temperatures at these sites, and Eastern Hemlock conservation zones could be strategically expanded there.

DWGNRA provides another context in which active HWA control is ongoing (Evans and Schreiner 2008). Since 2003, the park has treated about 25,000 Eastern 
Hemlock trees with insecticide (R.A. Evans, DWGNRA, Milford, PA, pers. comm.). Developed visitor-use areas have been prioritized for treatment to prevent Eastern Hemlock trees from declining and becoming hazard trees. The park's second priority has been treating riparian Eastern Hemlock forests to protect streams from loss of fisheries habitat, prevent stream-bank erosion, and maintain water quality. In upland areas, the preferred treatment method is imidacloprid tablet application to soil around Hemlock trunks (R.A. Evans, pers. comm.). The number of tablets applied increases with the square of the DBH of the tree (in inches), such that the number of tablets equates to $\mathrm{DBH}^{2} / 10$ for trees $>15 \mathrm{~cm}(6$ in.) in $\mathrm{DBH}$. Thus, a $25-\mathrm{cm}(10$-in) DBH tree requires 10 tablets, costing $\$ 7-10$ total for the tablets. These chemical costs are greater than for a soil drench, but tablet applications do not require mixing with water and are faster, safer, and cheaper to apply compared to a soil drench at this park (R.A. Evans, pers. comm.). Trees in riparian areas and near surface water are treated with imidacloprid stem injections, which cost about 10 times as much as tablet application for the same size tree. As at GSMNP, the park is concerned about both non-target effects of the treatment and consequences of leaving Eastern Hemlock trees untreated (Evans 2010). Key challenges facing park managers regarding use of chemical treatments include: identifying priority treatment sites to maximize benefit from limited resources; identifying non-target effects and weighing them against the effects of Eastern Hemlock loss; and balancing time and effort for chemical treatment with development of other treatments or longer-term management interventions (Evans and Schreiner 2008).

\section{Biocontrol}

Biocontrol is the release of predators or damaging agents, usually from the homeland of the organism targeted for treatment, to reduce a target organism in its introduced habitat (van Lenteren et al. 2006). In the US, the process of preparing biocontrols occurs under the Department of Agriculture's Animal and Plant Health Inspection Service (APHIS; Montgomery 2011). Potential biocontrol agents are usually first screened by examining organisms associated with a target organism in its native habitat. Next, feeding trials to determine food preferences of a potential biocontrol for the target organism and some non-target organisms are conducted in a controlled environment. If a biocontrol agent is authorized for release, the organism is released into the wild and researchers evaluate its ability to become established (van Lenteren et al. 2006, Montgomery 2011). Evaluations of full ecosystem effects of a biocontrol organism are rarely available, but there are numerous examples of biocontrols that have reduced the populations of their target organism (Van Driesche et al. 2010). A biocontrol program is considered successful if the cost and time (often decades) required for development and potential negative non-target effects are offset by reductions in the target organism compared to doing nothing or implementing other types of treatments.

Because, by definition, biocontrol involves release of one or more non-native organisms, numerous authors have noted the care with which biocontrol programs must be developed and the fact that ecological effects of a biocontrol in wildland 
ecosystems cannot be fully known until they are actually occurring (Simberloff and Stiling 1996, van Lenteren et al. 2006). The likelihood that a biocontrol organism will have immediate undesired effects, longer-term undesired effects (e.g., switching food sources to native species if the target organism is reduced by the biocontrol), or evolve to become invasive organisms themselves cannot be completely dismissed a priori, but the possibilities can be reduced through careful pre-release testing (van Lenteren et al. 2006).

Biocontrol currently represents a conundrum within NPS management policy (NPS 2006). Integrated Pest Management Coordinators in the NPS have discretion to authorize potential release of biocontrols approved for release in the US, which is then contingent upon development and approval of plans at individual parks (NPS 2006). The conundrum is that promoting establishment of exotic species (through release of biocontrols) within parks is generally inconsistent with NPS policy, but protecting native species is consistent with policy, as is limited use of exotic species to achieve resource objectives when viable alternatives are not available (NPS 2006). Two other important issues are that evaluations of non-target effects may or may not need to be more conservative for parks than for initial APHIS approval (but ability of the NPS to conduct these evaluations is limited), and park boundaries are porous to biocontrol spread such that biocontrols may inhabit parks whether or not released in parks.

Numerous biocontrol species have been released in North America as attempts to control HWA (Montgomery 2011), and it should be recognized that this has resulted in further exotic species introductions. Exotic species were needed as biocontrols because predatory insects native to eastern North America have not coevolved with HWA, are not specialists on HWA, and have not kept HWA densities sufficiently low to prevent death of Eastern Hemlock (Havill et al. 2011). A major current challenge is allowing sufficient time for careful field trials but still moving biocontrol programs forward while some living Eastern Hemlock trees remain (Vose et al. 2013).

Havill et al. (2012) reported on an unintended outcome that is already evident following the release of two beetle biocontrols for HWA. Laricobius nigrinus Fender (Black Beetle), native to western North America but not to eastern North America, has been released at numerous field sites since 2003 within Eastern Hemlock's range. This beetle has reduced HWA density, but Eastern Hemlock stands have not fully recovered from HWA infestation. Laricobius rubidus LeConte (Tooth-necked Fungus Beetle) is the only member of the genus endemic to eastern North America, and it feeds on HWA but prefers feeding on Pineus strobi Hartig (Pine Bark Adelgid) that in turn feeds on the native tree Pinus strobus L. (Eastern White Pine). The introduced biocontrol beetle has been hybridizing with the native beetle, and effects of this hybridization are unclear (Havill et al. 2012). Given that Eastern White Pine distribution overlaps with Eastern Hemlock and in many areas is a potential replacement tree when Eastern Hemlock is lost, the potential for adding another stressor to Eastern White Pine through release of an HWA biocontrol is disconcerting (Vose et al. 2013). 
Laricobius nigrinus, Laricobius osakensis Montgomery, Sasajiscymnus tsugae Sasaji McClure, Scymnus coniferarum Crotch, Scymnus sinuanodulus Yu and Yao, and Scymnus ningshanensis Yu and Yao are biocontrol insects released in GSMNP and DWGNRA (Evans and Schreiner 2008, Johnson et al. 2008). As of 2013, over 500,000 biocontrol beetles had been released in GSMNP (K. Johnson, pers. comm.) and over 80,000 in DWGNRA (Evans and Schreiner 2008). The NPS faces difficult choices regarding the use of biocontrol agents in parks because other treatments such as insecticides are not feasible to conduct over large areas, and when they are used, they can induce non-target effects; doing nothing (i.e. likely allowing hemlocks to die) would also have major effects. Because Eastern Hemlock-dependent organisms have not been fully identified within parks, there is no way to accurately predict potential non-target impacts of biocontrols, nor, conversely, the full impacts of Eastern Hemlock extirpation. Moreover, park boundaries are porous to biocontrol organisms and parks are likely to contain the organisms whether or not they are released directly within parks. This fact has led parks to release biocontrols for HWA: parks would receive any non-target impacts of biocontrols regardless, but by releasing biocontrols in parks, the parks could receive benefits faster (R.A. Evans, pers. comm.). As an overall strategy for biocontrol and forest health, careful analysis and monitoring of tradeoffs of biocontrols versus other treatments (including doing nothing), while also ensuring that potential replacement tree species (e.g., Eastern White Pine) are not harmed, seems prudent.

\section{Facilitate adaptation}

Eastern Hemlock has already been lost from appreciable areas of parks, and several strategies could help ecosystems adapt to current and potential Eastern Hemlock losses. A major principle in conservation biology is that minimizing other stressors can increase an indigenous ecosystem's ability to adapt to a primary stressor (Lovett et al. 2006). Actions that may promote adaptability of ecosystems formerly dominated by Eastern Hemlock could include, but are not limited to, reducing invasion of exotic plant species, maintaining soil health (e.g., limiting effects of pollution deposition), limiting unnatural levels of herbivory such as those caused by overabundance of White-Tailed Deer, and protecting and promoting colonizing native plant species (Webster et al. 2005). With opencanopy conditions after Eastern Hemlock mortality, invasion by exotic plants has already been reported in DWGNRA (Eschtruth and Battles 2009), and it is unclear if invasive species will persist and for how long. Management treatments have generally reduced target exotic plant species in localized projects on NPS lands, but park-wide effectiveness remains uncertain as does long-term effectiveness at controlling multiple invasions (Abella 2014). Eschtruth and Battles (2008) reported that intensive herbivory by White-Tailed Deer has significantly influenced transitions in post-HWA forests in DWGNRA, where Deer densities exceed 20 animals $/ \mathrm{km}^{2}$. Reduced White-Tailed Deer herbivory may correspond with increased opportunity for tree recruitment and establishment of understory plants, especially of plant species most susceptible to herbivory. 
Many of the tree species colonizing former Eastern Hemlock sites are deciduous trees not thought to provide the same functions as Eastern Hemlock, such as yearround amelioration of microclimates (Evans et al. 2011). In some areas such as the southern Appalachians, the conifer Eastern White Pine might be the closest match to Eastern Hemlock in terms of distribution and ecological traits (Vose et al. 2013). Consideration could be given to promoting Eastern White Pine or other native trees through planting or other means. This approach, however, poses a dilemma, because a first step in dealing with HWA-impacted areas might ideally be to monitor what plant species colonize former hemlock sites to evaluate whether management intervention is needed or desirable. However, taking the time to monitor sites prior to implementing managment could result in lost opportunities as the initial years during and after hemlock mortality might afford the most amenable window to establish desired vegetation. Experimentation and adaptive management would likely be needed to identify optimal techniques and species for assisting tree establishment. Eastern Hemlock habitats are specialized, and sites formerly vegetated by Hemlock will have unique soil properties such as thick, acidic O horizons that could affect plant recruitment (Finzi et al. 1998).

Some adaptation strategies discussed in Vose et al. (2013), primarily for nonNPS lands, illustrate some potential similarities and differences for application on NPS lands. For example, Vose et al. (2013) discussed introducing exotic tree species, such as those from HWA's native range that are resistant to HWA, at least within their native range, to attempt to mimic functions provided by Eastern Hemlock. The authors acknowledged that public acceptance of intentionally introducing (more) exotic species to public lands is uncertain, and it should also be noted that introducing exotic trees might interfere with colonization by native trees and may not be legally authorized. While a range of novel management options may warrant consideration (Vose et al. 2013), NPS (2006) management policy limits intentional introduction of exotic species to NPS lands and recommends promoting native species whenever possible. Other suggestions of Vose et al. (2013), such as collecting Eastern Hemlock genetic material for potential resistance breeding programs, or conserving remaining native species, would have greater congruence with NPS policy than introducing exotic trees (NPS 2006). Another management option discussed by Vose et al. (2013) was controlling aggressive native colonizers such as Great Rhododendron in post-HWA sites. NPS (2006) policy allows control of native species when natural processes have been interrupted. Such control measures are being taken in some parks where native trees have increased in density during a period in which natural fires have been suppressed. These woody species are being mechanically thinned so surface fire can be safely reintroduced (e.g., Teraoka 2012). Although Great Rhododendron can suppress tree-seedling establishment in the southern Appalachians (Ford et al. 2012), and thinning it may enhance recruitment of other species, the benefit of controlling Great Rhododendron on NPS lands is debatable because this species could perform some of the functions of Eastern Hemlock such as providing evergreen cover and creating a shaded, sparsely vegetated forest floor (Roberts et al. 2009). 


\section{Leverage existing National Park Service programs}

The NPS has several programs that could provide support to parks managing HWA and post-infestation conditions. The Exotic Plant Management Team program helps parks conduct treatments for exotic plants (Fraley et al. 2007) and may be a valuable resource for reducing exotic plant invasions already noted as a concern in post-HWA forests (Eschtruth and Battles 2009). The NPS also has a network of native-plant nurseries, housed at some parks or in collaboration with organizations such as Natural Resources Conservation Service plant materials centers, which could be sites for collecting and processing Eastern Hemlock genetic material and growing native plants for facilitated establishment on HWA sites. The Integrated Pest Management Program could provide numerous services, such as supporting scientific evaluations of specific biocontrol agents that would inform development of park management policies (e.g., Havill et al. 2011) and help parks balance tradeoffs resulting from a range of management alternatives representing difficult decisions (Vose et al. 2013). The Vegetation Inventory Program establishes vegetation-sampling plots across parks to produce maps of current vegetation and could represent a major source of reference information on distribution and composition of Eastern Hemlock Forest communities (Jenkins 2007). Moreover, the inventory plots could become long-term monitoring plots. To enhance utility, it is important to follow key vegetation-sampling principles such as using consistent sampling-unit sizes across sites to allow comparisons and employing unbiased sampling, which can be done in a stratified framework to maximize use of limited resources (Peet and Roberts 2013). Much has been learned from independent, park-created networks of monitoring plots such as at DWGNRA where plots have been re-measured since 1993, providing models for other parks and NPS-wide programs (Evans 2010). The Inventory and Monitoring Program (Fancy et al. 2009) could address specific questions regarding vegetation transitions in the aftermath of HWA and monitor effectiveness of management treatments such as facilitated colonization of native species. Moreover, a key priority as a foundation for management is inventorying and understanding organisms that are strongly associated with Eastern Hemlock. The Climate Change Program could predict potential impacts of introduced forest pests and future forest composition in specific parks (Iverson et al. 2008). To account for influences on forest composition, these scenarios must include multiple factors (e.g., other introduced forest pests, herbivory, disruption of natural disturbance regimes such as fire) that interact with, and sometimes overwhelm, climatic influences (Lovett et al. 2006).

\section{Conclusion}

Management of HWA and its impacts on parks would likely benefit from increased understanding of baselines for comparison, both for identication of Eastern Hemlock-dependent species and for evaluating management alternatives. Baird et al. $(2007,2009)$ identified Eastern Hemlock-associated arthropod species not only unknown in GSMNP, but never described to science. This knowledge gap is 
sobering in that even parks such as GSMNP visited by over 9 million people annually could lose Hemlock-associated species before the species have even been discovered. It may be difficult to develop adaptation strategies without understanding the degree of dependence of organisms on Eastern Hemlock, their capacity to adapt to using other habitat types when Hemlock dies, or their ability to persist with chronic exposure to treatment regimes aimed at maintaining Hemlock. When evaluating management options, it is useful to use potential replacement forests (often deciduous forests) as a likely outcome of some management strategies and assess that outcome as a basis for comparision with management actions that seek to preserve intact Eastern Hemlock forests, which are unlikely to be maintained in many areas (Roberts et al. 2009). For example, potential non-target effects of chemical treatments for HWA should probably be compared against a baseline that includes a forest without Eastern Hemlock (Falcone and DeWald 2010).

Potential for introduced forest-damaging agents to singly influence and interact with other factors to affect future forest composition of parks warrants increased attention. Lovett et al. (2006) concluded that forest destruction by introduced forest pests might overwhelm influences of climate change over coming decades. It is important to recognize that introduced pests had already dramatically impacted forests in national parks well before recent decades of contemporary climate change, most notably, the iconic extirpation of American Chestnut from introduced blight, which was complete in most areas by the 1950s (Ellison et al. 2005). As a result of American Chestnut loss, dramatically different forests exist to potentially adapt to future climates. American Chestnut is no longer present as a dominant overstory tree to experience today's climate or a future climate, a situation that will likely be repeated with the loss of Eastern Hemlock. Climate change is recognized as a major factor with the potential to shape ecosystems over the next several decades (Shafer 2012), but current science suggests that rather than being a single, causative agent, it is one of numerous, interacting factors that have shaped and will likely continue shaping park ecosystems (Eschtruth and Battles 2009, Lovett et al. 2006, Orwig et al. 2012). The primary current threat to Eastern Hemlock resources in national parks is an introduced insect species, which is shaping ecosystem trajectories perhaps for several future centuries.

\section{Acknowledgments}

This paper benefitted from discussions with NPS managers leading or involved with efforts to manage HWA: Richard Evans of DWGNRA, and Kristine Johnson and Jesse Webster of GSMNP. Richard Baird (Mississippi State University, Mississippi State, MS) shared ideas regarding identifying Eastern Hemlock-associated species. I also thank Sharon Altman (University of Nevada-Las Vegas, Las Vegas, NV) for formatting figures; and Sharon Altman, Peter Budde (NPS), and two anonymous reviewers for providing helpful comments on the manuscript. This manuscript is a contribution of the Biological Resource Management Division, NPS, of the US Government. Any use of trade names is for descriptive purposes only and does not imply endorsement by the US Government. 


\section{Literature Cited}

Abella, S.R. 2003. Quantifying ecosystem geomorphology of the southern Appalachian Mountains. Physical Geography 24:488-501.

Abella, S.R. 2014. Effectiveness of exotic plant treatments on National Park Service lands in the United States. Invasive Plant Science and Management 7:147-163.

Abella, S.R., V.B. Shelburne, and N.W. MacDonald. 2003. Multifactor classification of forest landscape ecosystems of Jocassee Gorges, southern Appalachian Mountains, South Carolina. Canadian Journal of Forest Research 33:1933-1946.

Adkins, J.K., and L.K. Rieske. 2013. Loss of a foundation forest species due to an exotic invader impacts terrestrial arthropod communities. Forest Ecology and Management 295:126-135.

Allen, M.C., J. Sheehan, T.L. Master, and R.S. Mulvihill. 2009. Responses of Acadian Flycatchers (Empidonax virescens) to Hemlock Woolly Adelgid (Adelges tsugae) infestation in Appalachian riparian forests. Auk 126:543-553.

Aukema, J.E., B. Leung, K. Kovacs, C. Chivers, K.O. Britton, J. Englin, S.J. Frankel, R.G. Haight, T.P. Holmes, A.M. Liebhold, D.G. McCullough, and B. Von Holle. 2009. Economic impacts of non-native forest insects in the continental United States. PLoS ONE 6:e24587.

Baird, R.E., C.E. Watson, and S. Woolfolk. 2007. Microfungi from bark of healthy and damaged American Beech, Fraser Fir, and Eastern Hemlock trees during an all taxa biodiversity inventory in forests of the Great Smoky Mountains National Park. Southeastern Naturalist 6:67-82.

Baird, R.E., S. Woolfolk, and C.E. Watson. 2009. Microfungi of forest litter from healthy American Beech, Fraser Fir, and Eastern Hemlock stands in Great Smoky Mountains National Park. Southeastern Naturalist 8:609-630.

Beatty, S.W. 1984. Influence of microtopography and canopy species on spatial patterns of forest understory plants. Ecology 65:1406-1419.

Becker, D.A., M.C. Brittingham, and C.B. Goguen. 2008. Effects of Hemlock Woolly Adelgid on breeding birds at Fort Indiantown Gap, Pennsylvania. Northeastern Naturalist 15:227-240.

Boettcher, S.E., and P.J. Kalisz. 1990. Single-tree influence on soil properties in the mountains of eastern Kentucky. Ecology 74:1365-1372.

Butin, E., A.H. Porter, and J. Elkinton. 2005. Adaptation during biological invasions and the case of Adelges tsugae. Evolutionary Ecology Research 7:887-900.

Cleavitt, N.L., A.K. Eschtruth, J.J. Battles, and T.J. Fahey. 2008. Bryophyte response to Eastern Hemlock decline caused by Hemlock Woolly Adelgid infestation. Journal of the Torrey Botanical Society 135:12-25.

Cowles, R.S. 2009. Optimizing dosage and preventing leaching of imidacloprid for management of Hemlock Woolly Adelgid in forests. Forest Ecology and Management 257:1026-1033.

Cowles, R.S., M.E. Montgomery, and C.A.S.-J. Cheah. 2006. Activity and residues of imidacloprid applied to soil and tree trunks to control Hemlock Woolly Adelgid (Hemiptera: Adelgidae) in forests. Journal of Economic Entomology 99:1258-1267.

Ellison, A.M., M.S. Bank, B.D. Clinton, E.A. Colburn, K. Elliott, C.R. Ford, D.R. Foster, B.D. Kloeppel, J.D. Knoepp, G.M. Lovett, J. Mohan, D.A. Orwig, N.L. Rodenhouse, W.V. Sobczak, K.A. Stinson, J.K. Stone, C.M. Swan, J. Thompson, B. Von Holle, and J.R. Webster. 2005. Loss of foundation species: Consequences for the structure and dynamics of forested ecosystems. Frontiers in Ecology and the Environment 9:479-486. 
Eschtruth, A.K., and J.J. Battles. 2008. Deer herbivory alters forest response to canopy decline caused by an exotic insect pest. Ecological Applications 18:360-376.

Eschtruth, A.K., and J.J. Battles. 2009. Acceleration of exotic plant invasion in a forested ecosystem by a generalist herbivore. Conservation Biology 23:388-399.

Eschtruth, A.K., N.L. Cleavitt, J.J. Battles, R.A. Evans, and T.J. Fahey. 2006. Vegetation dynamics in declining Eastern Hemlock stands: 9 years of forest response to Hemlock Woolly Adelgid infestation. Canadian Journal of Forest Research 36:1435-1450.

Eschtruth, A.K., R.A. Evans, and J.J. Battles. 2013. Patterns and predictors of survival in Tsuga canadensis populations infested by the exotic pest Adelges tsugae: 20 years of monitoring. Forest Ecology and Management 305:195-203.

Evans, D.M., W.M. Aust, C.A. Dolloff, B.S. Templeton, and J.A. Peterson. 2011. Eastern Hemlock decline in riparian areas from Maine to Alabama. Northern Journal of Applied Forestry 28:97-104.

Evans, R. 2010. Hemlock Woolly Adelgid and Hemlock ecosystems at Delaware Gap National Recreation Area. Pp. 61-69, In B. Onken and R. Reardon (Eds.). Fifth Symposium on Hemlock Woolly Adelgid in the Eastern United States, Asheville, NC, 17-19 August 2010. FHTET-2010-07. US Department of Agriculture, Forest Service, Forest Health Technology Enterprise Team, Morgantown, WV. 222 pp.

Evans, R., and J. Shreiner. 2008. Research, monitoring, and management of Eastern Hemlock forests at Delaware Water Gap National Recreation Area. Pp. 70-80, In B. Onken and R. Reardon (Eds.). Fourth Symposium on Hemlock Woolly Adelgid in the Eastern United States, Hartford, CT, 12-14 February 2008. FHTET-2008-01. US Department of Agriculture, Forest Service, Forest Health Technology Enterprise Team, Morgantown, WV. 339 pp.

Evans, R.A., E. Johnson, J. Shreiner, A. Ambler, J. Battles, N. Cleavitt, T. Fahey, J. Sciascia, and E. Pehek. 1996. Potential impacts of Hemlock Woolly Adelgid (Adelges tsugae) on Eastern Hemlock (Tsuga canadensis) ecosystems. Pp. 42-56, In S.M. Salome, T.C. Tigner, and R.C. Reardon (Eds.). Proceedings of the First Hemlock Woolly Adelgid Review, Charlottesville, VA, 12 October 1995. FHTET 96-10. US Department of Agriculture, Forest Service, Forest Health Technology Enterprise Team, Morgantown, WV. $74 \mathrm{pp}$.

Falcone, J.F., and L.E. DeWald. 2010. Comparisons of arthropod and avian assemblages in insecticide-treated and untreated Eastern Hemlock (Tsuga canadensis [L.] Carr) stands in Great Smoky Mountains National Park, USA. Forest Ecology and Management 260:856-863.

Fancy, S.G., J.E. Gross, and S.L. Carter. 2009. Monitoring the condition of natural resources in US national parks. Environmental Monitoring and Assessment 151:161-174.

Farnsworth, E.J., A.A. Barker Plotkin, and A.M. Ellison. 2012. The relative contributions of seed bank, seed rain, and understory vegetation dynamics to the reorganization of Tsuga canadensis forests after loss due to logging or simulated attack by Adelges tsugae. Canadian Journal of Forest Research 42:2090-2105.

Finzi, A.C., N. Van Breemen, and C.D. Canham. 1998. Canopy tree-soil interactions within temperate forests: Species effects on soil carbon and nitrogen. Ecological Applications $8: 440-446$.

Ford, C.R., and J.M. Vose. 2007. Tsuga canadenis (L.) Carr. mortality will impact hydrologic processes in southern Appalachian forest ecosystems. Ecological Applications 17:1156-1167.

Ford, C.R., K.J. Elliott, B.D. Clinton, B.D. Kloeppel, and J.M. Vose. 2012. Forest dynamics following Eastern Hemlock mortality in the southern Appalachians. Oikos 121:523-536. 
Fraley, N., C. Furqueron, T. Pernas, and E. Worsham. 2007. The National Park Service's exotic plant management teams in the Southeast and Caribbean. Natural Areas Journal 27:232-235.

Godman, R.M., and K. Lancaster. 1990. Tsuga canadensis (L.) Carr. Eastern Hemlock. [PAGE NUMBERS], In R.M. Burns and B.H. Honkala (Tech. Coords.). Silvics of North America. Vol. 1 Conifers. Agriculture Handbook 654. US Department of Agriculture, Forest Service, Washington, DC. 877 pp.

Goerlich, D.L., and R.D. Nyland. 2000. Natural regeneration of Eastern Hemlock: A review. Pp. 14-22, In K.A. McManus, K.S. Shields, and D.R. Souto (Eds.). Proceedings: Symposium on Sustainable Management of Hemlock Ecosystems in Eastern North America. General Technical Report GTR-NE-267. US Department of Agriculture, Forest Service, Northeastern Research Station, Newton Square, PA. 237 pp.

Haas, J.N., and J.H. McAndrews. 2000. The summer drought-related Hemlock (Tsuga canadensis) decline in eastern North America 5700 to 5100 years ago. Pp. 81-88, In K.A. McManus, K.S. Shields, and D.R. Souto (Eds.). Proceedings: Symposium on Sustainable Management of Hemlock Ecosystems in Eastern North America. General Technical Report GTR-NE-267. US Department of Agriculture, Forest Service, Northeastern Research Station, Newton Square, PA. 237 pp.

Harris, T.B., N. Rajakaruna, S.J. Nelson, and P.D. Vaux. 2012. Stressors and threats to the flora of Acadia National Park, Maine: Current knowledge, information gaps, and future directions. Journal of the Torrey Botanical Society 139:323-344.

Hart, J.L. 2008. Eastern Hemlock decline and persistence of disjunct populations near its southern boundary. Journal of Alabama Academy of Science 79:174-180.

Hart, J.L., and D. Shankman. 2005. Disjunct Eastern Hemlock (Tsuga canadensis) stands at its southern range boundary. Journal of the Torrey Botanical Society 132:602-612.

Havill, N.P., and R.G. Foottit. 2007. Biology and evolution of Adelgidae. Annual Review of Entomology 52:325-349.

Havill, N., M. Montgomery, and M. Keena. 2011. Hemlock Woolly Adelgid and its Hemlock hosts: A global perspective. Pp. 3-14, In B. Onken and R. Reardon (Eds.). Implementation and Status of Biological Control of the Hemlock Woolly Adelgid. FHTET-2011-04. United States Department of Agriculture, Forest Service, Forest Health Technology Enterprise Team, Morgantown, WV. 230 pp.

Havill, N.P., G. Davis, D.L. Mausel, J. Klein, R. McDonald, C. Jones, M. Fischer, S. Salom, and A. Caccone. 2012. Hybridization between a native and introduced predator of Adelgidae: An unintended result of classical biological control. Biological Control 63:359-369.

Hessl, A., and N. Pederson. 2013. Hemlock legacy project (HeLP): A paleoecological requiem for Eastern Hemlock. Progress in Physical Geography 37:114-129.

Hille Ris Lambers, J., J.S. Clark, and M. Lavine. 2005. Implications of seed banking for recruitment of southern Appalachian woody species. Ecology 86:85-95.

Howe, R.W., and M. Mossman. 1995. The significance of Hemlock for breeding birds in the western Great Lakes region. Pp. 125-139, In G. Mroz and J. Martin (Eds.). Hemlock Ecology and Management: Proceedings of a Regional Conference on Ecology and Management of Eastern Hemlock. University of Wisconsin, Madison, WI. 200 pp.

Ingwell, L.L., and E.L. Preisser. 2011. Using citizen science programs to identify host resistance in pest-invaded forests. Conservation Biology 25:182-188.

Ingwell, L.L., M. Miller-Pierce, R.T Trotter, and E.L. Preisser. 2012. Vegetation and invertebrate community response to Eastern Hemlock decline in southern New England. Northeastern Naturalist 19:541-558. 
Iverson, L.R., A.M. Prasad, S.N. Matthews, and M. Peters. 2008. Estimating potential habitat for 134 eastern US tree species under six climate scenarios. Forest Ecology and Management 254:390-406.

Jacobs, D.F. 2007. Toward development of silvical strategies for forest restoration of American Chestnut (Castanea dentata) using blight-resistant hybrids. Biological Conservation 137:497-506.

Jenkins, J.C., J.D. Aber, and C.D. Canham. 1999. Hemlock Woolly Adelgid impacts on community structure and N-cycling rates in Eastern Hemlock forests. Canadian Journal of Forest Research 29:630-645.

Jenkins, M.A. 2007. Vegetation communities of Great Smoky Mountains National Park. Southeastern Naturalist Special Issue 1:35-56.

Jetton, R.M., W.A. Whittier, W.S. Dvorak, and J.R. Rhea. 2010. Status of gene conservation for Eastern and Carolina Hemlock in the eastern United States. Pp. 93-99, In B. Onken and R. Reardon (Eds.). Fifth Symposium on Hemlock Woolly Adelgid in the Eastern United States, Asheville, North Carolina, 17-19 August 2010. FHTET-2010-07. US Department of Agriculture, Forest Service, Forest Health Technology Enterprise Team, Morgantown, WV. 222 pp.

Johnson, K., T. Remaley, and G. Taylor. 2008. Managing Hemlock Woolly Adelgid at Great Smoky Mountains National Park: Situation and response. Pp. 62-69, In B. Onken and R. Reardon (Eds.). Fourth Symposium on Hemlock Woolly Adelgid in the Eastern United States, Hartford, CT, 12-14 February 2008. FHTET-2008-01. US Department of Agriculture, Forest Service, Forest Health Technology Enterprise Team, Morgantown, WV. 339 pp.

Jonas, S.Z., W. Xi, J.D. Waldron, and R.N. Coulson. 2012. Impacts of Hemlock decline and ecological considerations for Hemlock stand restoration following Hemlock Woolly Adelgid outbreaks. Tree and Forestry Science and Biotechnology 6:22-26.

Kincaid, J.A. 2007. Compositional and environmental characteristics of Tsuga canadensis (L.) Carr. forests in the southern Appalachian Mountains, USA. Journal of the Torrey Botanical Society 134:479-488.

Kizlinski, M.L., D.A. Orwig, R.C. Cobb, and D.R. Foster. 2002. Direct and indirect ecosystem consequences of an invasive pest on forests dominated by Eastern Hemlock. Journal of Biogeography 29:1489-1503.

Knoepp, J.D., J.M. Vose, J.L. Michael, and B.C. Reynolds. 2012. Imidacloprid movement in soils and impacts on soil microarthropods in southern Appalachian Eastern Hemlock stands. Journal of Environmental Quality 41:469-478.

Koch, F.H., H.M. Cheshire, and H.A. Devine. 2006. Landscape-scale prediction of Hemlock Woolly Adelgid, Adelges tsugae (Homoptera: Adelgidae), infestation in the southern Appalachian Mountains. Environmental Entomology 35:1313-1323.

Krapfl, K.J., E.J. Holzmueller, and M.A. Jenkins. 2011. Early impacts of Hemlock Woolly Adelgid in Tsuga canadensis forest communities of the southern Appalachian Mountains. Journal of the Torrey Botanical Society 138:93-106.

Krapfl, K.J., E.J. Holzmueller, and M.A. Jenkins. 2012. Understory composition of five Tsuga canadensis-associated forest communities in Great Smoky Mountains National Park. Natural Areas Journal 32:260-269.

Lambdin, P., J. Grant, D. Paulsen, and A. Saxton. 2006. Invasion of the Hemlock Woolly Adelgid on Eastern Hemlock in the Great Smoky Mountains National Park. Journal of the Tennessee Academy of Science 81:49-54.

Liebhold, A.M., W.L. MacDonald, D. Bergdahl, and V.C. Mastro. 1995. Invasion by exotic forest pests: A threat to forest ecosystems. Forest Science Monographs 30. 49 pp. 
Lishawa, S.C., D.R. Bergdahl, and S.D. Costa. 2007. Winter conditions in Eastern Hemlock and mixed-hardwood deer wintering areas of Vermont. Canadian Journal of Forest Research 37:697-703.

Lovett, G.M., C.D. Canham, M.A. Arthur, K.C. Weathers, and R.D. Fitzhugh. 2006. Forest ecosystem responses to exotic pests and pathogens in eastern North America. BioScience 56:395-405.

Martin, K.L., and P.C. Goebel. 2012. Decline in riparian Tsuga canadensis forests of the central Appalachians across an Adelges tsugae invasion chronosequence. Journal of the Torrey Botanical Society 139:367-378.

McClure, M.S. 1996. Biology of Adelges tsugae and its potential for spread in the northeastern United States. Pp. 16-25, In S.M. Salome, T.C. Tigner, and R.C. Reardon (Eds.). Proceedings of the First Hemlock Woolly Adelgid Review, Charlottesville, Virginia, 12 October 1995. FHTET 96-10. US Department of Agriculture, Forest Service, Forest Health Technology Enterprise Team, Morgantown, WV. 74 pp.

Montgomery, M.E. 2011. Understanding federal regulations as guidelines for classical biological control programs. Pp. 25-40, In B. Onken and R. Reardon (Eds.). Implementation and Status of Biological Control of the Hemlock Woolly Adelgid. FHTET-2011-04. United States Department of Agriculture, Forest Service, Forest Health Technology Enterprise Team, Morgantown, WV. 230 pp.

Morin, R.S., A.M. Liebhold, and K.W. Gottschalk. 2009. Anisotropic spread of Hemlock Woolly Adelgid in the eastern United States. Biological Invasions 11:2341-2350.

National Park Service. 2006. Management Policies 2006. US Department of the Interior, National Park Service, US Government Printing Office, Washington, DC. 168 pp.

Orwig, D.A., and D.R. Foster. 1998. Forest response to the introduced Hemlock Woolly Adelgid in southern New England, USA. Journal of the Torrey Botanical Society 125:60-73.

Orwig, D.A., D.R. Foster, and D.L. Mausel. 2002. Landscape patterns of Hemlock decline in New England due to the introduced Hemlock Woolly Adelgid. Journal of Biogeography 29:1475-1487.

Orwig, D.A., R.C. Cobb, A.W. D’Amato, M.L. Kizlinski, and D.R. Foster. 2008. Multi-year ecosystem response to Hemlock Woolly Adelgid infestation in southern New England forests. Canadian Journal of Forest Research 38:834-843.

Orwig, D.A, J.R. Thompson, N.A. Povak, M. Manner, D. Niebyl, and D.R. Foster. 2012. A foundation tree at the precipice: Tsuga canadensis health after the arrival of Adelges tsugae in central New England. Ecosphere 3(1):10.

Paradis, A., J. Elkinton, K. Hayhoe, and J. Buonaccorsi 2008. Role of winter temperature and climate change on the survival and future range expansion of the Hemlock Woolly Adelgid (Adelges tsugae) in eastern North America. Mitigation and Adaptation Strategies for Global Change 13:541-554.

Peet, R.K., and D.W. Roberts. 2013. Classification of natural and semi-natural vegetation. Pp. 28-70, In E. van der Maarel and J. Franklin (Eds.). Vegetation Ecology. John Wiley and Sons, New York, NY. 572 pp.

Quimby, J.W. 1996. Value and importance of Hemlock ecosystems in the eastern United States. Pp. 1-8, In S.M. Salome, T.C. Tigner, and R.C. Reardon (Eds.). Proceedings of the First Hemlock Woolly Adelgid Review, Charlottesville, VA, 12 October 1995. FHTET 96-10. US Department of Agriculture, Forest Service, Forest Health Technology Enterprise Team, Morgantown, WV. 74 pp. 
Rentch, J., M.A. Fajvan, R.A. Evans, and B. Onken. 2009. Using dendrochronology to model Hemlock Woolly Adelgid effects on Eastern Hemlock growth and vulnerability. Biological Invasions 11:551-563.

Roberts, S.W., R. Tankersley, and K.H. Orvis. 2009. Assessing the potential impacts to riparian ecosystems resulting from Hemlock mortality in Great Smoky Mountains National Park. Environmental Management 44:335-345.

Rogers, R.S. 1980. Hemlock stands from Wisconsin to Nova Scotia: Transitions in understory composition along a floristic gradient. Ecology 61:178-193.

Rohr, J.R., C.G. Mahan, and K.C. Kim. 2009. Response of arthropod biodiversity to foundation species declines: The case of the Eastern Hemlock. Forest Ecology and Management 258:1503-1510.

Ross, R.M., R.M. Bennett, C.D. Snyder, J.A. Young, D.R. Smith, and D.P. Lemarie. 2003. Influence of Eastern Hemlock (Tsuga canadensis L.) on fish community structure and function in headwater streams of the Delaware River Basin. Ecology of Freshwater Fish 12:60-65.

Ross, R.M., L.A. Redell, R.M. Bennett, and J.A. Young. 2004. Mesohabitat use of threatened Hemlock forests by breeding birds of the Delaware River basin in northeastern United States. Natural Areas Journal 24:307-315.

Shafer, C.L. 2012. Chronology of awareness about US national park external threats. Environmental Management 50:1098-1110.

Siderhurst, L.A., H.P. Griscom, M. Hudy, and Z.J. Bortolot. 2010. Changes in light levels and stream temperatures with loss of Eastern Hemlock (Tsuga canadensis) at a southern Appalachian stream: Implications for Brook Trout. Forest Ecology and Management 260:1677-1688.

Simberloff, D., and P. Stiling. 1996. How risky is biological control? Ecology 77:19651974.

Small, M.J., C.J. Small, and G.D. Dreyer. 2005. Changes in a Hemlock-dominated forest following Woolly Adelgid infestation in southern New England. Journal of the Torrey Botanical Society 132:458-470.

Snyder, B.A., M.A. Callaham, and P.F. Hendrix. 2011. Spatial variability of an invasive earthworm (Amynthas agrestis) population and potential impacts on soil characteristics and millipedes in the Great Smoky Mountains National Park, USA. Biological Invasions 13:349-358.

Snyder, C.D., J.A. Young, D.P. Lemarié, and D.R. Smith. 2002. Influence of Eastern Hemlock (Tsuga canadensis) forests on aquatic invertebrate assemblages in headwater streams. Canadian Journal of Fisheries and Aquatic Science 59:262-275.

Souto, D., T. Luther, and B. Chianese. 1996. Past and current status of HWA in Eastern and Carolina Hemlock stands. Pp. 9-12, In S.M. Salome, T.C. Tigner, and R.C. Reardon (Eds.). Proceedings of the First Hemlock Woolly Adelgid Review, Charlottesville, VA, 12 October 1995. FHTET 96-10. US Department of Agriculture, Forest Service, Forest Health Technology Enterprise Team, Morgantown, WV. 74 pp.

Stadler, B., T. Müller, and D. Orwig. 2006. The ecology of energy and nutrient fluxes in hemlock forests invaded by Hemlock Woolly Adelgid. Ecology 87:1792-1804.

Teraoka, J.R. 2012. Forest restoration at Redwood National Park: A case study of an emerging program. Pp. 561-569, In R.B. Standiford, T.J. Weller, D.D. Piirto, and J.D. Stuart (Eds.). Proceedings of the Coast Redwood Forests in a Changing California: A Symposium for Scientists and Managers. General Technical Report PSW-GTR-238. US Department of Agriculture, Forest Service, Pacific Southwest Research Station. 675 pp. 
Tingley, M.W. D.A. Orwig, R. Field, and G. Motzkin. 2002. Avian response to removal of a forest dominant: Consequences of Hemlock Woolly Adelgid infestations. Journal of Biogeography 29:1505-1516.

Van Driesche, R.G., R.I. Carruthers, T. Center, M.S. Hoddle, J. Hough-Goldstein, L. Morin, L. Smith, D.L. Wagner, B. Blossey, V. Brancatini, R. Casagrande, C.E. Causton, J.J. Coetzee, J. Cuda, J. Ding, S.V. Fowler, J.H. Frank, R. Fuester, J. Goolsby, M. Grodowitz, T.A. Heard, M.P. Hill, J.H. Hoffman, J. Huber, M. Julien, M.T.K. Kairo, M. Kenis, P. Matson, J. Medal, R. Messing, R. Miller, A. Moore, P. Neuenschwander, R Newman, H. Norambuena, W.A. Palmer, R. Pemberton, A. Perez-Panduro, P.D. Pratt, M. Rayamajhi, S. Salom, D. Sands, S. Schooler, M. Schwarzlander, A. Sheppard, R. Shaw, P.W. Tipping, and R.D van Klinken. 2010. Classical biological control for the protection of natural ecosystems. Biological Control 54:S2-S33.

van Lenteren, J.C., J. Bale, F. Bigler, H.M.T. Hokkanen, and A.J.M. Loomans. 2006. Assessing risks of releasing exotic biological control agents of arthropod pests. Annual Review of Entomology 51:609-634.

Vose, J.M., D.N. Wear, A.E. Mayfield, and C.D. Nelson. 2013. Hemlock Woolly Adelgid in the southern Appalachians: Control strategies, ecological impacts, and potential management responses. Forest Ecology and Management 291:209-219.

Webster, C.R., M.A. Jenkins, and J.H. Rock. 2005. Long-term response of spring flora to chronic herbivory and deer exclusion in Great Smoky Mountains National Park, USA. Biological Conservation 125:297-307.

Webster, J. 2010. Management of Hemlock Woolly Adelgid in Great Smoky Mountains National Park. Pp. 57-60, In B. Onken and R. Reardon (EDs.). Fifth Symposium on Hemlock Woolly Adelgid in the Eastern United States, Asheville, NC, 17-19 August 2010. FHTET-2010-07. US Department of Agriculture, Forest Service, Forest Health Technology Enterprise Team, Morgantown, WV. 222 pp.

Webster, J.R., K. Morkeski, C.A. Wojculewski, B.R. Niederlehner, E.F. Benfield, and K.J. Elliott. 2012. Effects of Hemlock mortality on streams in the southern Appalachian Mountains. American Midland Naturalist 168:112-131.

Willeford Bair, M. 2002. Eastern Hemlock (Tsuga canadensis) mortality in Shenandoah National Park. Pp. 61-66, In B. Onken, R. Reardon, and L. Lashomb (Eds.). Proceedings: Hemlock Woolly Adelgid in the Eastern United States Symposium. New Jersey Agricultural Experiment Station, New Brunswick, NJ. 403 pp.

Yamasaki, M., R.M. DeGraaf, and J.W. Lanier. 2000. Wildlife habitat associations in Eastern Hemlock: Birds, smaller mammals, and forest carnivores. Pp. 135-143, In K.A. McManus, K.S. Shields, and D.R. Souto (Eds.). Proceedings: Symposium on Sustainable Management of Hemlock Ecosystems in Eastern North America. General Technical Report GTR-NE-267. US Department of Agriculture, Forest Service, Northeastern Research Station, Newton Square, PA. 237 pp.

Yorks, T.E., D.J. Leopold, and D.J. Raynal. 2003. Effects of Tsuga canadensis mortality on soil water chemistry and understory vegetation: Possible consequences of an invasive insect herbivore. Canadian Journal of Forest Research 33:1525-1537. 